Article

\title{
Past, Present, and Future Nutrient Quality of a Small Southeastern River: A Pre-Dam Assessment
}

\author{
Jonathan M. Miller and Paul M. Stewart * \\ Department of Biological and Environmental Sciences, Troy University, Troy, AL 36082, USA; \\ E-Mail: jmiller7557@troy.edu \\ * Author to whom correspondence should be addressed; E-Mail: mstewart@troy.edu; \\ Tel.: +1-334-670-3932; Fax: +1-334-670-3662.
}

Received: 21 April 2013; in revised form: 14 June 2013 / Accepted: 27 June 2013 /

Published: 8 July 2013

\begin{abstract}
Riverine dams alter both the physical environment and water chemistry, thus affecting species assemblages within these environments. In the United States, dam construction is on the decline and there is a growing trend for dam removal. The Choctawhatchee, Pea, and Yellow Rivers Watershed Management Authority had initiated the permitting process for placing a reservoir dam on the Little Choctawhatchee River (LCR), a tributary to the Choctawhatchee River. The purpose of the proposed reservoir was water supply, and while the permit application has been suspended, history shows that this or related projects are likely to arise in the future. This study collected data on nutrient quality seasonally (four times) from 12 sites in the LCR watershed from October 2007 to June 2008 in order to determine pre-dam conditions and to compare these data to historical and regional information. Historical and current nutrient concentrations were elevated throughout the watershed, in most cases above suggested criteria, and indicated that water quality of the river was and continues to be nutrient rich. A future reservoir at recent levels of water quality will likely be highly eutrophic, and anthropogenic influences will further stress this ecosystem and its water quality as the urban region expands.
\end{abstract}

Keywords: Choctawhatchee; Little Choctawhatchee River; water quality; reservoir; dam; nutrients; wastewater; phosphorus; nitrogen 


\section{Introduction}

The environmental effect of dams on riverine systems includes the degradation of habitat and river morphology [1,2] and the decline of water quality [3,4]. The number of dams being built across the United States began decreasing after the 1960s [5]. Of the 1995 dams reported in the National Inventory of Dams (NID) for Alabama, the number of dams being built has decreased in Alabama since the 1960s, with the majority of dams built being low-hazard earth dams [5] which are typically small scale farm ponds.

Riverine impoundments often impact water chemistry by increasing concentrations of nutrients [6], and decreasing levels of dissolved oxygen. Reservoirs not only increase certain chemical concentrations to harmful levels, but also reduce needed parameters to critical levels by acting as annual sinks for organic and inorganic compounds [7]. Even though a reservoir may act as a flow-through system, dams often act as large nutrient traps that slow nutrient advancement [3]. Concentrations and ratios of nutrients play a critical role in eutrophication and the development of algal blooms [8], which can be toxic to humans and animals and are often a nuisance. When nuisance algal blooms die, these can deplete the reservoir of oxygen leading to fish kills, noxious odors, and other problems associated with decaying organic matter. In addition, regional variations play a vital role in the processing of retained nutrients in reservoirs [9].

The Choctawhatchee, Pea, and Yellow Rivers Watershed Management Authority (CPYRWMA) had initiated the permitting processes for the placement of a reservoir dam on the Little Choctawhatchee River (LCR) for a drinking water supply, though the recent permit has been suspended. The need for baseline nutrient information is important when little historic data are available, so that the future nutrient status of the reservoir can be predicted. This study focused on the nutrient quality of the LCR and its tributaries. The objectives were to: (1) describe the nutrient conditions of the river over a one-year period; (2) compare nutrient data with historical and regional measurements and to nutrient criteria; and (3) discuss future water quality of a proposed reservoir, if built.

\section{Materials and Methods}

\subsection{Study Area}

The LCR is a tributary to the Choctawhatchee River located in southeastern Alabama, USA (Figure 1). The LCR system drains the northern and western sides of Dothan, AL and primarily borders the Dale and Houston County line. The watershed covers about $430 \mathrm{~km}^{2}$ and is comprised of low-gradient streams with sand and marl bottoms. Urban development and agriculture are currently the dominate land uses within this area. Conversion of forested habitats for urbanization and agricultural purposes has caused numerous changes in stream habitats including destabilization of stream banks, increased sedimentation from eroding fields and developing areas, chemical changes from fertilizers and biocides, and alteration of light, thermal regimes, and hydrologic conditions [10].

The dam's intended location was upstream of an old power dam at Dale County Road 121, and is between Highway 123 and County Road 9 on the border of the Dale and Houston County line, near Panther and Bear Creeks [11]. The proposed reservoir of the LCR would have had a normal pool depth of $9.75 \mathrm{~m}$ and a normal pool area of 592 ha [11]. 
Figure 1. Little Choctawhatchee River near Dothan in southeast Alabama.

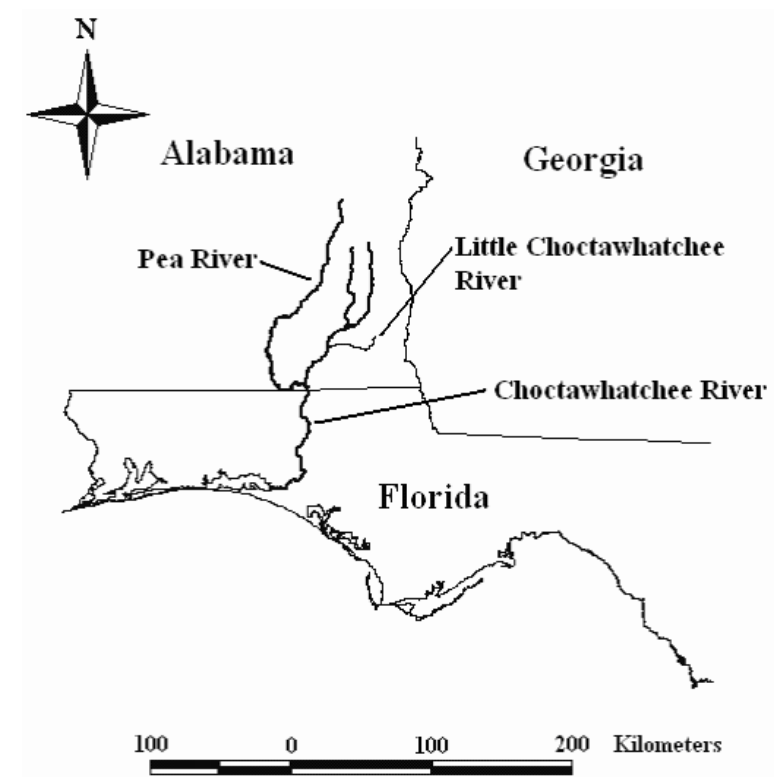

\subsection{Nutrient Sample Collection and Analysis}

Twelve sites were selected within the LCR watershed (six sites on the Little Choctawhatchee River and six sites on tributaries) (Figure 2). Using standard sampling protocols [12], nutrient variables were measured seasonally (four times) at each site to provide baseline nutrient data for the watershed. Nutrients measured included total phosphorus (TP), orthophosphate (OP), and nitrate $\left(\mathrm{NO}_{2}+\mathrm{NO}_{3}\right)$. All grab samples for laboratory analysis were collected at approximately $15 \mathrm{~cm}$ depth, in flowing water where available, in acid-washed $(10 \% \mathrm{HCl}) 125 \mathrm{~mL}$ Nalgene ${ }^{\circledR}$ narrow-mouth HDPE bottles, transported on ice to the laboratory, and analyzed within appropriate time frames [12]. Grab samples were taken in separate containers for TP (unfiltered), and $\mathrm{OP}$ and $\mathrm{NO}_{3}$ (filtered, $0.45 \mu \mathrm{m}$ ). Duplicate water samples were collected for $>10 \%$ of the samples for quality control. The Hach DR/2800 (Hach Company, Loveland, CO, USA) was used to measure all nutrient concentrations. All means (in our study and others referenced) were calculated from grab samples, therefore not implementing discharge to determine mean loading. Measurements under the detection limit were calculated as one half the detection limit in computing means. Total phosphorus (TP) was measured with Hach Method 8190 (Hach Company) using program 3036, with detection limits ranging from 0.02 to $1.14 \mathrm{mg} / \mathrm{L}$ P [13]. Orthophosphate (OP) concentrations were measured with Hach program 3025 PhosVer3 (Ascorbic Acid) Method 8048, with detection limits from 0.01 to $0.81 \mathrm{mg} / \mathrm{L}$ P [14]. Nitrate $\left(\mathrm{NO}_{3}\right)$ was measured using procedure 8192 [15], with detection limits ranging from 0.01 to $0.50 \mathrm{mg} / \mathrm{L}$ $\mathrm{NO}_{3}-\mathrm{N}$. This method converts nitrite $\left(\mathrm{NO}_{2}\right)$ to nitrate $\left(\mathrm{NO}_{3}\right)$, and actually measures $\mathrm{NO}_{2}+\mathrm{NO}_{3}$ as $\mathrm{N}$. All values found to be above detection limits were derived by diluting samples with deionized water prior to analysis [12].

\subsection{Data Analysis}

Box plots were used to visually compare nutrients over the entire year (four samplings) by site. Nutrient information gathered in the present study was compared to past nutrient data of the LCR found in the 
literature, regional data, U.S. Environmental Protection Agency (EPA) regional criteria [16], phosphorus levels considered to be eutrophic by Dodds et al. [17], and nitrogen levels indicative of excessive algae growth [18].

Figure 2. The Little Choctawhatchee River watershed demonstrating general land use and the twelve stream sampling sites near Dothan in southeast Alabama, USA.

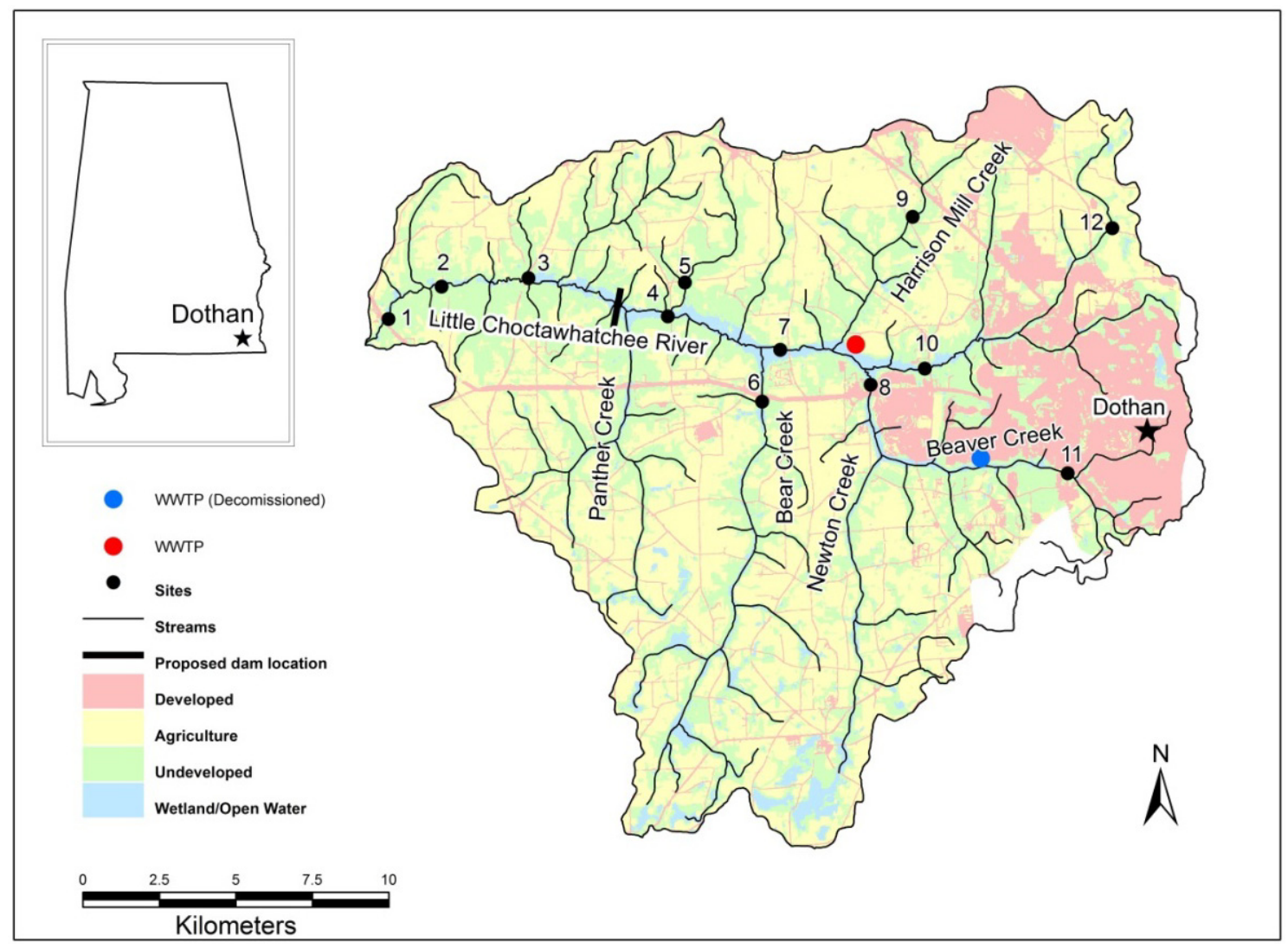

\section{Results}

\subsection{Recent and Seasonal Condition of the LCR Watershed}

Total phosphorus (TP) varied from below detection limits $(<0.02 \mathrm{mg} / \mathrm{L} \mathrm{P}$, used in mean as $0.01 \mathrm{mg} / \mathrm{L} \mathrm{P}$ ) in the summer of 2008 at site 9 to $0.62 \mathrm{mg} / \mathrm{L} \mathrm{P}$ at site 8 during the first sampling which occurred in the fall of 2007. Of 48 samples taken at 12 sites over four seasons, only two were found to have concentrations below the U.S. EPA recommended criteria $(0.0365 \mathrm{mg} / \mathrm{L} \mathrm{P})$ for this region, and six samples were found with a concentration below the eutrophic level as suggested by Dodds et al. [17] $(0.075 \mathrm{mg} / \mathrm{L} \mathrm{P})$. Yearly TP means (using half the detection limit for numbers recorded below detection limits) by site ranged from $0.091 \mathrm{mg} / \mathrm{L} \mathrm{P}$ at site 9 to $0.367 \mathrm{mg} / \mathrm{L} \mathrm{P}$ at site 8 , with an overall mean of $0.175 \mathrm{mg} / \mathrm{L} \mathrm{P}$ for the entire study (mean of four sampling events over all sites) (Table 1). Total phosphorus concentrations over the entire year were much higher at sites 7 and 8 (sites below wastewater treatment plants), and lowest at sites 5, 6, 9, 10, 11, and 12 (Figure 3). The site most directly downstream of the proposed dam location (site 3) had a mean TP concentration of $0.194 \mathrm{mg} / \mathrm{L} \mathrm{P}$, over five times the U.S. EPA recommended criterion for rivers and streams and almost ten times the criterion for lakes and reservoirs $(0.020 \mathrm{mg} / \mathrm{L} \mathrm{P})$ [16]. 
Table 1. Mean, median, variance, minimum, and maximum total phosphorus (TP), orthophosphate $(\mathrm{OP})$, and nitrate $\left(\mathrm{NO}_{3}\right)$ concentrations in $\mathrm{mg} / \mathrm{L}$ by season $(n=12)$ and for the year. TP recommended stream criteria: U.S. Environmental Protection Agency (EPA) [16], $0.0365 \mathrm{mg} / \mathrm{L} \mathrm{P}$; Dodds et al. [17], $0.075 \mathrm{mg} / \mathrm{L} \mathrm{P.}$

\begin{tabular}{|c|c|c|c|c|c|}
\hline $\begin{array}{c}\text { Nutrients by } \\
\text { Season }\end{array}$ & $\begin{array}{c}\text { Mean } \\
(\mathrm{mg} / \mathrm{L})\end{array}$ & $\begin{array}{c}\text { Median } \\
(\mathrm{mg} / \mathrm{L})\end{array}$ & $\begin{array}{c}\text { Variance } \\
(\mathrm{mg} / \mathrm{L})\end{array}$ & $\begin{array}{c}\text { Minimum } \\
(\mathrm{mg} / \mathrm{L})\end{array}$ & $\begin{array}{c}\text { Maximum } \\
(\mathrm{mg} / \mathrm{L})\end{array}$ \\
\hline \multicolumn{6}{|c|}{ Fall (7 October 2007) } \\
\hline $\mathrm{TP}$ & 0.274 & 0.236 & 0.031 & 0.09 & 0.62 \\
\hline $\mathrm{OP}$ & 0.146 & 0.103 & 0.019 & 0.01 & 0.39 \\
\hline $\mathrm{NO}_{3}$ & 0.838 & 0.825 & 0.230 & 0.05 & 1.71 \\
\hline \multicolumn{6}{|c|}{ Winter (8 January 2008) } \\
\hline $\mathrm{TP}$ & 0.135 & 0.139 & $<0.001$ & 0.10 & 0.16 \\
\hline OP & 0.049 & 0.033 & 0.002 & $<0.01$ & 0.12 \\
\hline $\mathrm{NO}_{3}$ & 0.618 & 0.630 & 0.138 & 0.10 & 1.47 \\
\hline \multicolumn{6}{|c|}{ Spring (4 April 2008) } \\
\hline $\mathrm{TP}$ & 0.150 & 0.134 & 0.004 & 0.08 & 0.28 \\
\hline $\mathrm{OP}$ & 0.100 & 0.096 & 0.004 & $<0.01$ & 0.23 \\
\hline $\mathrm{NO}_{3}$ & 0.552 & 0.510 & 0.126 & 0.20 & 1.50 \\
\hline \multicolumn{6}{|c|}{ Summer (29 June 2008) } \\
\hline $\mathrm{TP}$ & 0.141 & 0.093 & 0.016 & $<0.02$ & 0.46 \\
\hline $\mathrm{OP}$ & 0.093 & 0.059 & 0.009 & 0.01 & 0.33 \\
\hline $\mathrm{NO}_{3}$ & 0.864 & 0.710 & 0.347 & 0.16 & 2.25 \\
\hline \multicolumn{6}{|c|}{ Mean/Year 2007-2008 } \\
\hline $\mathrm{TP}$ & 0.1750 & 0.142 & 0.015 & $<0.02$ & 0.62 \\
\hline $\mathrm{OP}$ & 0.0969 & 0.059 & 0.009 & $<0.01$ & 0.39 \\
\hline $\mathrm{NO}_{3}$ & 0.7177 & 0.600 & 0.216 & 0.05 & 2.25 \\
\hline
\end{tabular}

Figure 3. Box plot of total phosphorus (TP) concentrations (as $\mathrm{P}$ ) in $\mathrm{mg} / \mathrm{L}$ by site (4 samples/site) in the Little Choctawhatchee River watershed from October 2007 to June 2008. Reference line indicates U.S. EPA suggested criteria for TP as $\mathrm{P}(0.0365 \mathrm{mg} / \mathrm{L}$ as $\mathrm{P})$.

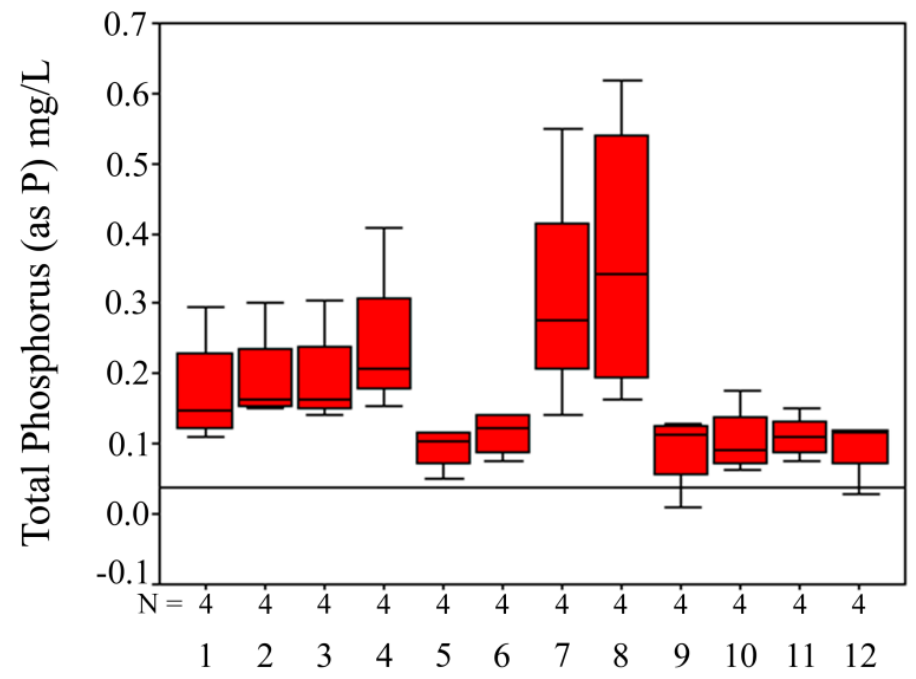

Site Number 
Orthophosphate $(\mathrm{OP})$ ranged from below detection limits $(0.01 \mathrm{mg} / \mathrm{L} \mathrm{P}$, reported as $0.005 \mathrm{mg} / \mathrm{L} \mathrm{P})$ in the spring at site 12 and the lowest detectable limit in winter at site $3(0.01 \mathrm{mg} / \mathrm{L})$, to $0.39 \mathrm{mg} / \mathrm{L}$ at site 8 during fall 2007. Yearly OP means by site ranged from $0.025 \mathrm{mg} / \mathrm{L}$ at sites 9 and 12 to $0.231 \mathrm{mg} / \mathrm{L}$ at site 7 (site below a WWTP). The overall mean for all samples for the year was $0.097 \mathrm{mg} / \mathrm{L}$ (Table 1). As with TP, OP at sites 7 and 8 (both below WWTPs) was highest for the year, and lowest at 5, 6, 9, 10, 11, and 12 (Figure 4).

Figure 4. Box plot of orthophosphate (OP) concentrations in $\mathrm{mg} / \mathrm{L}$ by site (4 samples/site) in the Little Choctawhatchee River watershed from October 2007 to June 2008. Reference line indicates U.S. EPA suggested criteria for TP as P $(0.0365 \mathrm{mg} / \mathrm{L}$ as P).

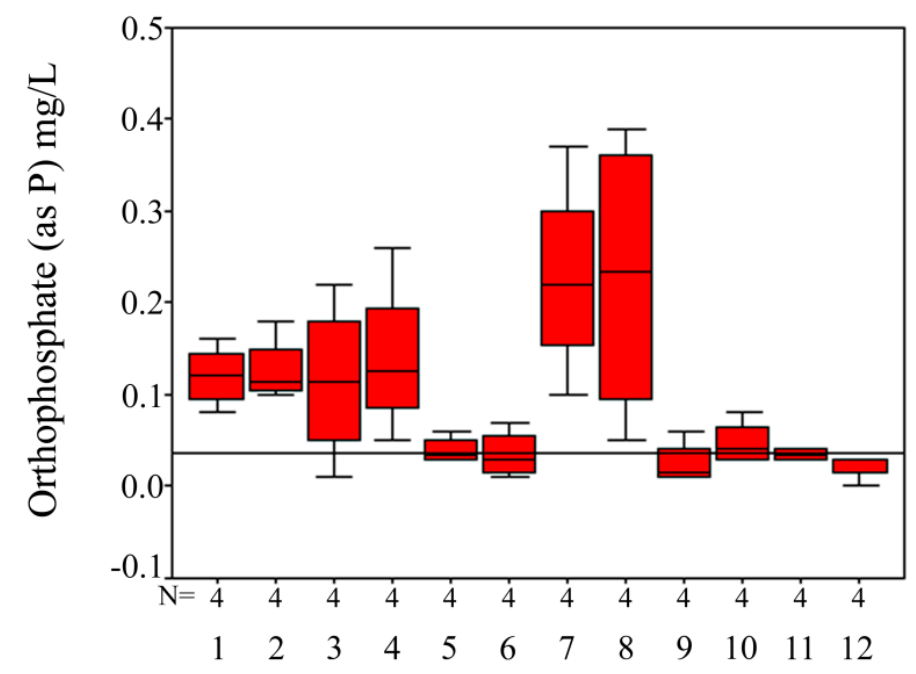

Site Number

Nitrate $\left(\mathrm{NO}_{3}\right)$ was lowest during fall at site 6 with $0.05 \mathrm{mg} / \mathrm{L} \mathrm{N}$, and highest in summer at site 5, measuring $2.25 \mathrm{mg} / \mathrm{L} \mathrm{N}$ (Figure 5). Yearly $\mathrm{NO}_{3}$ means ranged from $0.128 \mathrm{mg} / \mathrm{L} \mathrm{N}$ at site 6 to $1.490 \mathrm{mg} / \mathrm{L} \mathrm{N}$ at site 5 (Table 1). The yearly overall mean from all sites for $\mathrm{NO}_{3}$ for the watershed was $0.718 \mathrm{mg} / \mathrm{L} \mathrm{N}$ (Table 1). The highest yearly means were at sites 5 and 9 while the lowest were found at sites 6 and 11. The site most directly downstream of the proposed dam location had a mean $\mathrm{NO}_{3}$ concentration of $0.668 \mathrm{mg} / \mathrm{L} \mathrm{N}$, which almost exceeds the total nitrogen (TN) U.S. EPA recommended criterion for rivers and streams $(0.69 \mathrm{mg} / \mathrm{L} \mathrm{N})$ and is almost twice the $\mathrm{TN}$ criterion for lakes and reservoirs $(0.36 \mathrm{mg} / \mathrm{L} \mathrm{N})$ [16].

By season, TP mean was highest at $0.274 \mathrm{mg} / \mathrm{L} \mathrm{P}$ during fall and lowest at $0.135 \mathrm{mg} / \mathrm{L} \mathrm{P}$ during winter. Orthophosphate had the highest seasonal mean of $0.146 \mathrm{mg} / \mathrm{L} \mathrm{P}$ in fall and lowest at $0.049 \mathrm{mg} / \mathrm{L} \mathrm{P}$ in winter. The mean $\mathrm{NO}_{3}$ by season was highest $(0.864 \mathrm{mg} / \mathrm{L} \mathrm{N})$ in summer and lowest $(0.552 \mathrm{mg} / \mathrm{L} \mathrm{N})$ in spring (Table 1$)$.

Elevated TP, OP, and $\mathrm{NO}_{3}$ were found throughout the year at sites 1, 2, 3, 4, 7, and 8 (primarily main channel sites downstream of WWTPs). Of all sites, the top five highest nutrient concentrations for all three nutrients almost always included sites 4,7 , and 8 for each sample and for means in this study. Site 8 always had high TP, and only during one sampling event did it not record the highest TP of all sites. Site 6 had the lowest $\mathrm{NO}_{3}$ levels, except for winter sampling, where site 6 was second lowest behind site 12 . 
Figure 5. Box plot of nitrate $\left(\mathrm{NO}_{3}\right)$ concentrations in $\mathrm{mg} / \mathrm{L}$ by site (4 samples/site) in the Little Choctawhatchee River watershed from October 2007 to June 2008. Reference line indicates U.S. EPA suggested criteria for TN as N $(0.69 \mathrm{mg} / \mathrm{L}$ as $\mathrm{P})$.

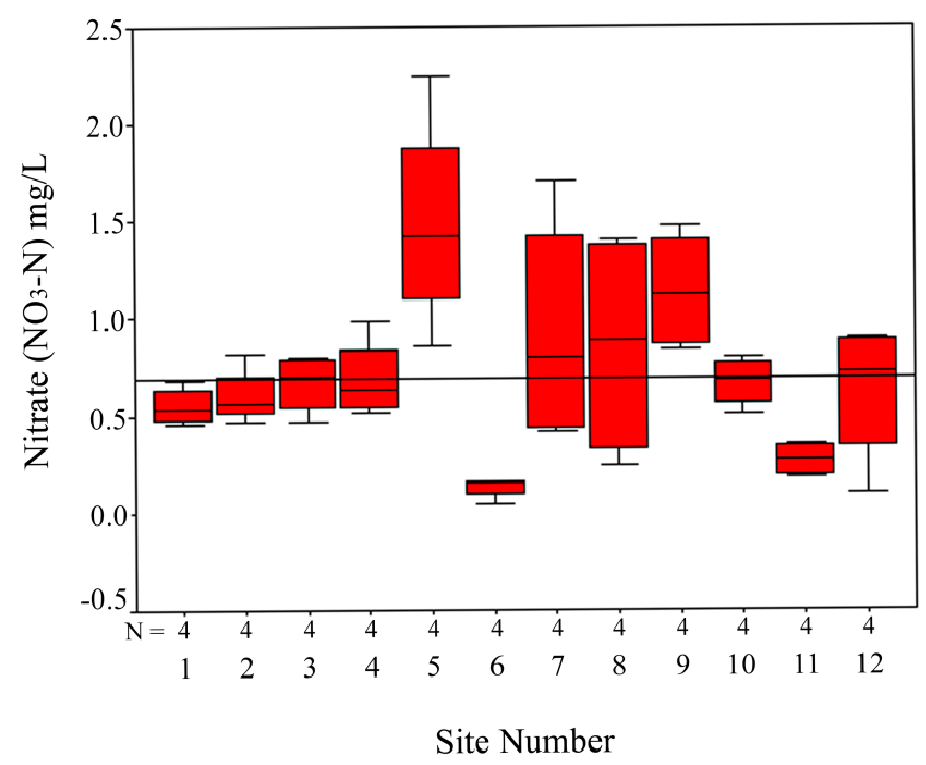

\subsection{Comparison to Past LCR Nutrient Data}

Data were retrieved from other studies on the LCR to compare these values to past and more recent conditions (Tables 2-5). These data were examined to determine whether water quality was changing throughout the watershed and at individual sites. Site 8 TP had been decreasing over time in regards to historical data, until this study indicated an increase in TP (Table 2). Total phosphorus at sites 5 and 12 appeared to be lower in this and the Geological Survey of Alabama (GSA) study [19] than in the past, while site 11 showed a substantial increase from 2007-2008 to 2009-2010 [10,19,20]. Data published by Mullen [21] from 1999 to 2003 were lower than recent findings for OP at sites 4 and 8, while most other data suggested that OP was similar to the recent findings for most sites where data were found (Table 3).

A comparison of $\mathrm{NO}_{3}$ concentrations suggested that these concentrations have been quite high in the past (ranging from 0.17 to $4.09 \mathrm{mg} / \mathrm{L}$ ) and remain so with site means in our study ranging from 0.13 to $1.49 \mathrm{mg} / \mathrm{L}$ (Table 4), and 0.3 to $2.2 \mathrm{mg} / \mathrm{L}$ in the GSA study [19]. Site 5 had elevated $\mathrm{NO}_{3}$ concentrations for all samples in the our study, and these values were similar to results from Sawyer et al. [10] and Cook et al. [19] that found concentrations $\geq 2.0 \mathrm{mg} / \mathrm{L} \mathrm{N}$ (Table 4). Further, nutrient data collected from multiple subwatersheds within the Choctawhatchee River basin suggested that our LCR TP concentrations were lower than most, OP concentrations were in the middle of the range, and $\mathrm{NO}_{3}$ concentrations were somewhat similar, though all were elevated (Table 5; [10,20,22,23]). 
Table 2. Minimum, maximum, and mean (if available) of total phosphorus (TP) concentrations from historical sources in chronological sampling order, with coinciding sites, along with our data.

\begin{tabular}{|c|c|c|c|c|c|c|c|c|c|c|}
\hline Source & Sample Year & TP & Site 1 & Site 4 & Site 5 & Site 6 & Site 8 & Site 10 & Site 11 & Site 12 \\
\hline \multirow{3}{*}{ ADEM [24] } & \multirow{3}{*}{1999} & Min & & & & & 0.19 & & & \\
\hline & & Max & & & & & 0.91 & & & \\
\hline & & Mean & & & & & 0.48 & & & \\
\hline \multirow{3}{*}{ Mullen (PE) [21] } & \multirow{3}{*}{ 1999-2003 } & Min & BDL & 0.02 & & 0.03 & 0.15 & $\mathrm{BDL}$ & & \\
\hline & & Max & 0.22 & 0.18 & & 0.12 & 0.24 & 0.13 & & \\
\hline & & Mean & 0.13 & 0.14 & & 0.08 & 0.19 & 0.06 & & \\
\hline \multirow{3}{*}{ Mullen (CERS) [21] } & \multirow{3}{*}{ 1999-2003 } & Min & 0.15 & 0.20 & & 0.11 & 0.23 & 0.07 & & \\
\hline & & Max & 0.54 & 0.58 & & 0.21 & 0.31 & 0.18 & & \\
\hline & & Mean & 0.29 & 0.32 & & 0.17 & 0.26 & 0.13 & & \\
\hline Sawyer et al. [10] & 2001 & Value & & & 0.73 & & & & & \\
\hline Heath [20] & 2004 & Value & & & & & & & 0.61 & 0.76 \\
\hline \multirow{3}{*}{ ADEM [24] } & \multirow{3}{*}{2004} & Min & & & & & 0.04 & & & \\
\hline & & Max & & & & & 0.29 & & & \\
\hline & & Mean & & & & & 0.18 & & & \\
\hline \multirow{3}{*}{ ADEM [24] } & \multirow{3}{*}{2005} & Min & & & & & 0.03 & & & \\
\hline & & $\operatorname{Max}$ & & & & & 0.26 & & & \\
\hline & & Mean & & & & & 0.16 & & & \\
\hline \multirow{3}{*}{ Chakravarty [23] } & \multirow{3}{*}{$2006-2007$} & Min & 0.12 & 0.20 & & & & 0.09 & & \\
\hline & & Max & 0.36 & 0.34 & & & & 0.38 & & \\
\hline & & Mean & 0.23 & 0.27 & & & & 0.18 & & \\
\hline \multirow{3}{*}{ Our Study } & \multirow{3}{*}{ 2007-2008 } & Min & 0.11 & 0.15 & 0.05 & 0.08 & 0.16 & 0.06 & 0.08 & 0.03 \\
\hline & & Max & 0.30 & 0.41 & 0.12 & 0.14 & 0.62 & 0.18 & 0.15 & 0.12 \\
\hline & & Mean & 0.18 & 0.24 & 0.10 & 0.12 & 0.37 & 0.11 & 0.11 & 0.10 \\
\hline \multirow{3}{*}{ Cook et al. [19] } & \multirow{3}{*}{ 2009-2010 } & Min & $\mathrm{BDL}$ & & BDL & BDL & & & BDL* & BDL* \\
\hline & & Max & 0.13 & & 0.06 & 0.05 & & & 0.74 & 0.04 \\
\hline & & Mean & 0.06 & & 0.02 & 0.02 & & & 0.36 & 0.02 \\
\hline
\end{tabular}

Notes: Value $=$ One measurement; $\mathrm{PE}=$ Polyenvironmental Corporation duplicated analysis of [21];

$\mathrm{BDL}=$ Below detection limit; * = Exact site location varied by $<5 \mathrm{~km}$.

Table 3. Minimum, maximum, and mean (if available) of orthophosphate (OP) concentrations from historical sources in chronological sampling order, with coinciding sites, along with our data.

\begin{tabular}{ccccccccccc}
\hline Source & Sample Year & OP & Site 1 & Site 4 & Site 5 & Site 6 & Site 8 & Site 10 & Site 11 & Site 12 \\
\hline \multirow{3}{*}{ Mullen [21] } & & Min & BDL & BDL & & BDL & 0.08 & BDL & & \\
\cline { 3 - 11 } & \multirow{2}{*}{$1999-2003$} & Max & 0.22 & 0.14 & & 0.11 & 0.23 & 0.10 & & \\
\cline { 3 - 11 } & & Mean & 0.08 & 0.07 & & 0.06 & 0.14 & 0.04 & & \\
\hline Sawyer et al. [10] & 2001 & Value & & & 0.11 & & & & & \\
\hline Heath [20] & 2004 & Value & & & & & & & 0.11 & 0.09 \\
\hline \multirow{3}{*}{ Our Study } & \multirow{2}{*}{$2007-2008$} & Min & 0.08 & 0.05 & 0.03 & 0.01 & 0.05 & 0.03 & 0.03 & BDL \\
\cline { 2 - 10 } & & Max & 0.16 & 0.26 & 0.06 & 0.07 & 0.39 & 0.08 & 0.04 & 0.03 \\
\cline { 3 - 10 } & & Mean & 0.12 & 0.14 & 0.04 & 0.04 & 0.23 & 0.05 & 0.03 & 0.03 \\
\hline
\end{tabular}


Table 4. Minimum, maximum, and mean (if available) of nitrate $\left(\mathrm{NO}_{2}+\mathrm{NO}_{3}\right)$ concentrations from historical sources in chronological sampling order, with coinciding sites, along with our data.

\begin{tabular}{|c|c|c|c|c|c|c|c|c|c|c|}
\hline Source & Sample Year & $\mathrm{NO}_{3}$ & Site 1 & Site 4 & Site 5 & Site 6 & Site 8 & Site 10 & Site 11 & Site 12 \\
\hline \multirow{3}{*}{ ADEM [24] } & \multirow{3}{*}{1999} & Min & & & & & 0.17 & & & \\
\hline & & Max & & & & & 2.56 & & & \\
\hline & & Mean & & & & & 1.33 & & & \\
\hline \multirow{3}{*}{ Mullen (PE) [21] } & \multirow{3}{*}{ 1999-2003 } & Min & 0.82 & 0.72 & & 0.90 & 1.12 & 0.98 & & \\
\hline & & Max & 3.58 & 4.09 & & 1.06 & 1.69 & 3.42 & & \\
\hline & & Mean & 1.80 & 1.81 & & 0.97 & 1.42 & 1.96 & & \\
\hline \multirow{3}{*}{ Mullen (CERS) [21] } & \multirow{3}{*}{ 1999-2003 } & Min & 0.40 & 0.80 & & 0.30 & 1.00 & 0.80 & & \\
\hline & & Max & 1.70 & 1.70 & & 0.50 & 1.30 & 1.30 & & \\
\hline & & Mean & 1.20 & 1.30 & & 0.40 & 1.20 & 0.90 & & \\
\hline Sawyer et al. [10] & 2001 & Value & & & 2.00 & & & & & \\
\hline Heath [20] & 2004 & Value & & & & & & & 0.30 & 1.10 \\
\hline \multirow{3}{*}{ ADEM [24] } & \multirow{3}{*}{2004} & Min & & & & & 0.50 & & & \\
\hline & & $\operatorname{Max}$ & & & & & 3.40 & & & \\
\hline & & Mean & & & & & 1.60 & & & \\
\hline \multirow{3}{*}{ ADEM [24] } & \multirow{3}{*}{2005} & Min & & & & & 0.29 & & & \\
\hline & & Max & & & & & 2.12 & & & \\
\hline & & Mean & & & & & 0.95 & & & \\
\hline \multirow{3}{*}{ Our Study } & \multirow{3}{*}{$2007-2008$} & Min & 0.46 & 0.52 & 0.86 & 0.05 & 0.24 & 0.51 & 0.18 & 0.10 \\
\hline & & Max & 0.68 & 0.99 & 2.25 & 0.16 & 1.41 & 0.80 & 0.35 & 0.90 \\
\hline & & Mean & 0.56 & 0.69 & 1.49 & 0.13 & 0.86 & 0.67 & 0.27 & 0.61 \\
\hline \multirow{3}{*}{ Cook et al. [19] } & \multirow{3}{*}{ 2009-2010 } & Min & BDL & & 0.7 & 0.3 & & & $0.1^{*}$ & $0.4^{*}$ \\
\hline & & Max & 5.7 & & 2.3 & 1.9 & & & 3.6 & 1.5 \\
\hline & & Mean & 1.7 & & 1.9 & 0.6 & & & 1.3 & 1.0 \\
\hline
\end{tabular}

Notes: Value $=$ One measurement; $\mathrm{PE}=$ Polyenvironmental Corporation; $*=$ Exact site location varied by $<5 \mathrm{~km}$.

Table 5. Historical means of total phosphorus (TP), orthophosphate (OP), and nitrate $\left(\mathrm{NO}_{3}\right)$ in studies on the Choctawhatchee River watershed. Note: Our study in one watershed (LCR), others within multiple watersheds within the Choctawhatchee River drainage.

\begin{tabular}{cccccc}
\hline Source & Sample Year & TP & OP & NO $_{3}$ & No. Sites \\
\hline Mullen [22] & $1999-2003$ & 0.29 & 0.07 & 0.74 & 10 \\
Sawyer et al. [10] & 2001 & 0.77 & 0.13 & 0.66 & 49 \\
Heath [20] & 2004 & 0.60 & 0.29 & 0.54 & 44 \\
Chakravarty [23] & $2006-2007$ & 0.24 & N/A & N/A & 48 \\
Our Study & $2007-2008$ & 0.18 & 0.10 & 0.72 & 12 (4 seasons) \\
\hline
\end{tabular}

\subsection{Comparison to Regional Data}

Several historical regional studies were found that reported TP concentrations that could be compared to the data collected in this study (Table 5). Of other Alabama rivers studied, from 1999 to 2001 [25] and 2006 to 2007 [23], most had TP concentrations that were within $0.06 \mathrm{mg} / \mathrm{L}$ of our mean 
concentration, though one was half the LCR mean TP concentration and two were over four times the concentration found in our study (Table 6). A Georgia-Florida drainage study (1992 to 1996) found mean OP levels for primary agricultural streams to be $0.06 \mathrm{mg} / \mathrm{L}$ and $0.08 \mathrm{mg} / \mathrm{L}$ for urban sites [26], which was slightly lower than the mean OP concentration of $0.097 \mathrm{mg} / \mathrm{L}$ in our study.

Table 6. Mean total phosphorus (TP) concentrations of the Little Choctawhatchee River watershed (our study) versus those from 1999 to 2001 in selected rivers of Alabama, the Choctawhatchee River watershed from 2006 to 2007, and historical studies of rivers throughout the south and 381 U.S. riverine sites.

\begin{tabular}{|c|c|c|}
\hline Rivers of Alabama & Location & $\begin{array}{c}\text { Mean TP } \\
\text { Concentrations }(\mathrm{mg} / \mathrm{L}) \\
\end{array}$ \\
\hline $\begin{array}{l}\text { Little Choctawhatchee River } \\
\text { drainage (our study) }\end{array}$ & (12 sites) throughout drainage & 0.18 \\
\hline $\begin{array}{l}\text { Alabama River } \\
\text { McPherson et al. }[25]\end{array}$ & Claiborne, Alabama & 0.09 \\
\hline $\begin{array}{l}\text { Black Warrior River } \\
\text { McPherson et al. [25] }\end{array}$ & $\begin{array}{l}\text { Below Bankhead Lock and Dam } \\
\text { near Bessemer, Alabama }\end{array}$ & 0.80 \\
\hline $\begin{array}{l}\text { Bogue Chitto Creek } \\
\text { McPherson et al. [25] }\end{array}$ & Memphis, Alabama & 1.07 \\
\hline $\begin{array}{l}\text { Cahaba River } \\
\text { McPherson et al. [25] }\end{array}$ & Centreville, Alabama & 0.21 \\
\hline $\begin{array}{l}\text { Chattooga River } \\
\text { McPherson et al. [25] }\end{array}$ & Above Gaylesville, Alabama & 0.14 \\
\hline $\begin{array}{l}\text { Cahaba Valley Creek } \\
\text { McPherson et al. [25] }\end{array}$ & Cross Creek Road at Pelham, Alabama & 0.14 \\
\hline $\begin{array}{l}\text { Pintlalla Creek } \\
\text { McPherson et al. [25] }\end{array}$ & $\begin{array}{l}\text { Liberty Church Road near } \\
\text { Pintlalla, Alabama }\end{array}$ & 0.15 \\
\hline $\begin{array}{l}\text { Threemile Branch } \\
\text { McPherson et al. [25] }\end{array}$ & $\begin{array}{l}\text { North Boulevard at } \\
\text { Montgomery, Alabama }\end{array}$ & 0.22 \\
\hline $\begin{array}{l}\text { Tombigee River } \\
\text { McPherson et al. [25] }\end{array}$ & $\begin{array}{l}\text { Below Coffeeville Lock and Dam } \\
\text { near Coffeeville, Alabama }\end{array}$ & 0.14 \\
\hline $\begin{array}{l}\text { Choctawhatchee Watershed } \\
\text { Chakravarty [23] }\end{array}$ & (48 sites) throughout drainage & 0.24 \\
\hline \multicolumn{3}{|l|}{ Other U.S. Rivers } \\
\hline Smith et al. [27] & 381 U.S. riverine sites (1974 to 1981) & 0.13 \\
\hline Spruill et al. [28] & $\begin{array}{l}\text { Albemarle-Pamlico Basin of North } \\
\text { Carolina and Virginia (1992 to 1995) }\end{array}$ & 0.05 \\
\hline Kleiss et al. [29] & Mississippi River (1984 to 1993) & 0.16 \\
\hline Kleiss et al. [29] & Yazoo River, Mississippi (1984 to 1993) & 0.26 \\
\hline Atkins et al. [30] & Mobile River Basin, Alabama (1998 to 1999) & 0.10 \\
\hline
\end{tabular}

\subsection{Comparison to Nutrient Criteria}

Nutrient criteria were established by the U.S. EPA to control excess nutrients and associated problems. Total phosphorus levels exceeding the U.S. EPA ecoregional nutrient criterion $(0.0365 \mathrm{mg} / \mathrm{L}$ 
as P) were found in historical data at most sites. Specifically, site 8 by the Alabama Department of Environmental Management (ADEM) [24], site 5 by Sawyer et al. [10], sites 1, 4, 6, 8, 9, and 10 by Mullen [21], sites 11 and 12 by Heath [20], and sites 1, 4, and 10 by Chakravarty [23] (Table 2). The mean TP concentrations of historical data ranged from almost two times to well over an order of magnitude higher than the recommended criterion. Sawyer et al. [10] also found elevated TP levels throughout the Choctawhatchee River watershed in 2001 (mean $=0.76 \mathrm{mg} / \mathrm{L}$ ), along with Mullen [22] finding elevated levels throughout the Little Choctawhatchee (mean $=0.44 \mathrm{mg} / \mathrm{L})$ and Choctawhatchee River (mean $=0.29 \mathrm{mg} / \mathrm{L}$ ) watersheds.

All samples in our study exceeded the U.S. EPA nutrient criterion for TP except for site 9 and 12 in June 2008, in which site 9 was below the detection limit of $0.02 \mathrm{mg} / \mathrm{L} \mathrm{P}$. Forty four of the 48 samples collected during this study exceeded the TP nutrient criterion by two times or more, the highest TP concentration found exceeded the criterion by nearly 17 times, and the overall mean of TP exceeded the criterion by almost five times.

The mean yearly value for TP was more than two times the eutrophic level as reported by Dodds et al. [17]. The yearly OP mean for all samples for the year was $0.0969 \mathrm{mg} / \mathrm{L}$, which was more than the TP level determined to be eutrophic by Dodds et al. [17]. The U.S. EPA ecoregional nutrient criterion for total nitrogen (TN) in streams and rivers is $0.69 \mathrm{mg} / \mathrm{L} \mathrm{N} \mathrm{[16],} \mathrm{meanwhile} \mathrm{Maidment} \mathrm{[18]}$ reported that $0.5 \mathrm{mg} / \mathrm{L} \mathrm{NO}_{3}-\mathrm{N}$ was indicative of excess algal growth. Nitrate (nitrate + nitrite) concentrations alone in this study exceeded TN criteria limits in 20 samples, and exceeded $0.5 \mathrm{mg} / \mathrm{L}$ in 31 of the 48 samples. Eight of these $\mathrm{NO}_{3}$ samples were almost, if not more than, twice the TN criterion. The highest measured $\mathrm{NO}_{3}$ concentration was over three times the TN criterion, and over four times Maidment's [18] criteria. Two of the seasonal means of the 12 sites, along with the overall mean, exceeded the $\mathrm{TN}$ criterion as well (Table 1). In addition to $\mathrm{NO}_{3}$ concentrations in our study exceeding U.S. EPA TN criterion levels, levels exceeding nutrient criterion were also found by ADEM [24] (site 8), Mullen [21] (sites 1, 4, 6, 8, and 10), and Cook et al. [19] (sites 1, 5, 6, 11, and 12) (Table 4).

\section{Discussion}

\subsection{Recent and Seasonal Condition of the LCR Watershed}

The LCR watershed has been stressed by the impacts of the surrounding urban and agricultural area. Habitat has been altered, nutrients are elevated, and mussel assemblages have been devastated [31]. Elevated levels of nutrients in an aquatic system can cause increased turbidity due to free-floating algae, the build-up of toxic cyanobacterial blooms, or unattractive dense filamentous algae that can cause odor problems and oxygen deficiency when decaying. Many of the sites (1-4, 7, and 8) measured in this study had elevated TP, $\mathrm{OP}$, and $\mathrm{NO}_{3}$ levels throughout the year. These sites have cultivated crop land percentages from $20 \%$ to $29.9 \%$ and urban developed percentages from $1 \%$ to 16\% (excluding developed open areas) [32]. Developed areas do not have to make up a large percentage of a watershed to have a major impact (e.g., WWTP, industrial effluent, impervious surface runoff, etc.). Urbanization impacts have been shown, in this study and others (e.g., [33,34]), to yield higher concentrations of phosphorus (OP and TP), and as little as 5\% urban land-use can lead to increases in OP year round [35]. 
Major contributors of phosphorus exist in watersheds, including WWTPs, urban storm-water, industrial discharge, livestock operations, precipitation runoff and soil erosion from croplands, runoff from lawns and gardens, and septic tank seepage near open water sources [36]. The increased concentrations of TP and OP near WWTPs were a good indication of where much of the nutrients were originating. The WWTP that released effluent into Beaver Creek (downstream of site 11) is now decommissioned, and effluent has been rerouted to the Little Choctawhatchee WWTP (upstream of site 7).

Fertilizers are one of the main sources of nitrogen compounds in water. Nitrate levels can persist in streams due to slow movement through the water table to streams [37]. These can be elevated further under drought conditions, as in this study [38], which leaves streams fed predominantly by ground water. If elevated levels of nitrogen fertilizer were applied in the past in this area, their effects could be seen for many years (up to decades) in the future [37]. Additional problem sources include release of by-products of industrial processes and sewage treatment, which occur in the LCR watershed [39]. With the possibility of impoundment of the LCR being suggested again in the future, as it has multiple times in the past, it must be noted that nutrient retention and accumulation of nitrogen may increase by many times (9 to 44) as a result of impoundment [40], and may also increase upstream from the reservoir as a result of reduced flow velocities.

In addition to high phosphorus, streams that drain agricultural catchments usually have higher nitrogen concentrations than urban and undeveloped areas [33], but similar or even higher levels have sometimes been found as a result of urbanization [41-43]. Elevated $\mathrm{NO}_{3}$ concentrations at site 5 could be due to pastures bordering the stream and a high percentage of cultivated crops [32], though the more recent study by Cook et al. [19] indicated similar elevated levels throughout the LCR watershed, and corresponded with our study with the majority of $\mathrm{NO}_{3}$ levels exceeding $0.5 \mathrm{mg} / \mathrm{L}$ in fall and summer.

\subsection{Comparison to Historical Data}

Historical data on nutrients were limited in the LCR watershed, but did provide some data for eight of the twelve sites. Total phosphorus concentrations measured in the past and in our study indicated that elevated nutrients levels were and remain a problem in the watershed, though more recent values reported by Cook et al. [19] were somewhat lower. Concentrations of all nutrients measured tended to be much higher below WWTPs than other sites in our study. Elevated nutrient levels are likely due to pressures being placed on the system from the surrounding agricultural, industrial, and urban input. As these contributions intensify with increasing population and urban expansion, these issues will grow.

\subsection{Comparison to Regional Data}

Other Alabama rivers studied from 1999 to 2001 [25] and 2006 to 2007 [23] had TP concentrations that were similar to our mean LCR watershed TP concentration, though two of the nine TP concentrations reported in McPherson et al. [25] greatly exceeded the mean LCR TP level (Table 6). Exceptions having much higher concentrations were Bogue Chitto Creek, in Dallas County, Alabama and the Black Warrior River near Bessemer, Alabama, which recorded means of 1.09 and $0.80 \mathrm{mg} / \mathrm{L}$, respectively [25]. Nutrient levels reported by McPherson et al. [25], suggested that there were elevated TP levels throughout the state that were higher than ecoregional nutrient criteria and demonstrated a need for regulation of phosphorus throughout the state [23]. 
Berndt et al. [26] found that $30 \%$ of the Georgia-Florida sites reported had TP concentrations higher than $0.1 \mathrm{mg} / \mathrm{L}$, which is the non-regulatory U.S. EPA TP goal, which poses a nuisance algal threat when exceeded. Of the 48 samples taken in our study, 40 samples ( $>80 \%)$, had TP concentrations exceeding the non-regulatory goal. Alabama, along with many other states, has not developed state-specific criteria and can only compare data with non-regulatory TP levels set as a desired U.S. EPA goal. Examination of other studies across the United States suggested that mean TP concentrations in the Choctawhatchee and the LCR watersheds ranged among the middle of other watersheds.

\subsection{Comparison to Nutrient Criteria}

The U.S. EPA ecoregional nutrient criterion for total phosphorus in streams and rivers is $0.0365 \mathrm{mg} / \mathrm{L} \mathrm{P}$ [16]. Dodds et al. [17] proposed that $0.075 \mathrm{mg} / \mathrm{L}$ TP indicated a eutrophic condition for temperate streams. Of 48 samples taken in this study across the LCR watershed, only four had TP concentrations below the suggested eutrophic level that Dodds et al. [17] proposed, and only one of the samples taken in this study (2007-2008) was in the oligotrophic category (i.e., $<0.025 \mathrm{mg} / \mathrm{L}$ ). With 22 of the 48 samples having at least two times the proposed eutrophic level of TP [17], and 12 sample concentrations over five times the U.S. EPA ecoregional nutrient criterion of TP, these levels suggest that if any reservoir were built it would be quite eutrophic. The U.S. EPA ecoregional nutrient criterion for total nitrogen $(\mathrm{TN})$ in streams and rivers is $0.69 \mathrm{mg} / \mathrm{L}$ [16]. Nitrate (nitrate + nitrite) concentrations alone in our study exceeded TN criteria limits in 20 of the 48 samples and the overall mean.

\subsection{Future Consideration of Potential Reservoir Impacts}

Excess nutrient levels shown by past and more recent studies suggest that any reservoir established in the area with these reported phosphorus and nitrogen levels would be a eutrophic system. Cyanobacterial blooms, excess nutrients, and variable dissolved oxygen concentrations (with potential anoxia) and $\mathrm{pH}$ levels are all characteristics of eutrophic lakes [17]. Stream nutrients usually increase with land-use intensity [17,44,45], human population density [17,46], and impervious surfaces. Elevated nutrient levels usually support greater algal biomass, and have been observed in many urban streams (e.g., [47,48]). Dense algal concentrations have occurred yearly in at least one area of the watershed (site 11, Figure 6), and could also occur in any future reservoir within the system. A future reservoir on the LCR, if built, will likely be highly eutrophic, and anthropogenic influences will further stress this ecosystem and its water quality as the population in the region continues to grow.

Comparisons of watersheds to determine future eutrophic conditions can be very difficult due to spatial and temporal variables and the lack of consistent data [49,50]. Cook et al. [19] reported nutrient loading about $8 \mathrm{~km}$ downstream of the proposed dam location (current study site 1; $3776 \mathrm{t} \mathrm{N} /$ year, $82 \mathrm{t} \mathrm{TP} /$ year) and these should also be considered in the natural processes of the system prior to impoundment. 
Figure 6. Photograph of Site 11 (Beaver Creek on Honeysuckle Rd.) during September 2008.

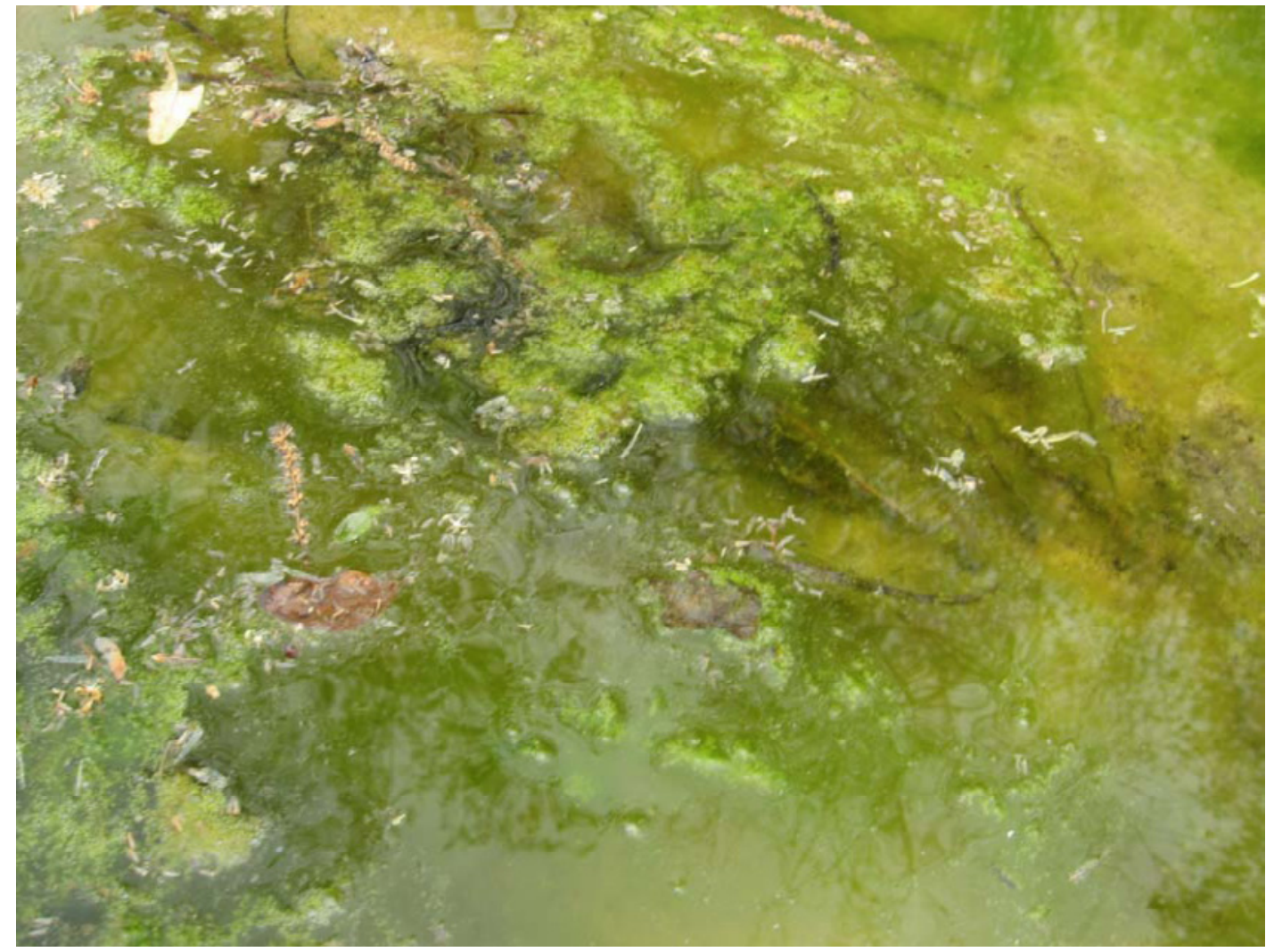

\section{Conclusions}

In conclusion, this study suggests that nutrients are excessive in the LCR watershed. Nutrient levels in areas not impacted by WWTPs remain in excess, with some TP levels four times greater than the U.S. EPA recommended criteria. Historical nutrient levels of the watershed were similar yet elevated, as was regional TP throughout the state of Alabama, whereas lower levels of nutrients were reported for neighboring states.

The need for additional sources of water may be extensive within the next 50 years in the "high growth scenario" in Coffee, Dale, Geneva, and Houston Counties and around the developing Dothan area [11]. Regardless, the future water quality of the proposed reservoir will need regulated nutrient levels to reduce deleterious effects. The Choctawhatchee River is one of the very few medium to large free-flowing rivers remaining in the southeastern U.S. The majority of all medium to large rivers in the United States are currently dammed, but nationwide more dams are currently being removed than built [51]. Since the times that dams were being rapidly built across the U.S. and knowledge of their impacts were lacking, it is now recognized that altering natural river systems degrades ecosystem services.

\section{Acknowledgements}

We thank Michael Mullen (Choctawhatchee Riverkeeper), Barbara Gibson (Director of the Choctawhatchee, Pea, and Yellow Rivers Watershed Management Authority), Lisa Huff (Alabama Department of Environmental Management), Ashley Peters (Department of Conservation and Natural 
Resources), and Jeremy Browning and J. Murray Hyde (Troy University) for the information and assistance that they provided.

\section{Conflict of Interest}

The authors declare no conflict of interest.

\section{References}

1. Ligon, F.K.; Dietrich, W.E.; Trush, W.J. Downstream ecological effects of dams: A geomorphic perspective. BioScience 1995, 45, 183-193.

2. De Mérona, B.; Albert, P. Ecological monitoring of fish assemblages downstream of a hydroelectric dam in French Guiana (South America). Regul. Rivers 1999, 15, 339-351.

3. Ward, J.V.; Stanford, J.A. Ecological Factors Controlling Stream Zoobenthos with Emphasis on Thermal Modification of Regulated Streams. In The Ecology of Regulated Streams; Stanford, J.A., Ed.; Plenum Publishers: New York, NY, USA, 1979; pp. 35-53.

4. Lessard, J.L.; Hayes, D.B. Effects of elevated water temperature on fish and macroinvertebrate communities below small dams. River Res. Appl. 2003, 19, 721-732.

5. United States Army Corps of Engineers (USACOE) Web Page. Corps Map: National Inventory of Dams. Available online: http://geo.usace.army.mil/pgis/f?p=397:12: (accessed on 13 August 2007).

6. Hannan, H.H. Chemical Modifications in Reservoir-Regulated Streams. In The Ecology of Regulated Sreams; Ward, J.V., Stanford, J.A., Eds.; Plenum Press: New York, NY, USA, 1979; pp. 75-94.

7. Ahearn, D.S.; Sheibley, R.W.; Dahlgren, R.A. Effects of river regulation on water quality in the lower Mokelumne River, California. River Res. Appl. 2005, 21, 651-670.

8. Redfield, A.C. The biological control of chemical factors in the environment. Am. Sci. 1958, 46, 205-221.

9. Kelly, V.J. Influence of reservoirs on solute transport: A regional-scale approach. Hydrol. Process. 2001, 15, 1227-1249.

10. Sawyer, J.; Stewart, P.M.; Simon, T.P.; Mullen, M.; Bennett, H. Comparison of water quality, habitat, and land use variables driving macroinvertebrate and fish assemblages of the Choctawhatchee-Pea Watershed, southern Alabama. Aquat. Ecosyst. Health 2004, 7, 85-99.

11. United States Army Corps of Engineers (USACOE). Water Supply Alternatives Evaluation Study for Southeast Alabama Supplemental Report; Choctawhatchee, Pea, and Yellow Watershed Management Authority, Troy University: Troy, AL, USA, 2005.

12. American Public Health Association (APHA). Standard Methods for the Examination of Water and Wastewater, 21st ed.; American Public Health Association, American Waterworks Association, and Water Environment Federation (WEF): Washington, DC, USA, 2005.

13. Hach Company. Phosphorus, Total (0.00 to $\left.3.50 \mathrm{mg} / \mathrm{L} \mathrm{PO}_{4^{3-}}\right)$ Method 8190 . In DR/4000 Spectrophotometer Handbook; Hach Company: Loveland, CO, USA, 1995; pp. 523-529.

14. Hach Company. Phosphorus, Reactive (0 to $2.500 \mathrm{mg} / \mathrm{L} \mathrm{PO}_{4^{3}}$ ) Method 8048. In DR/4000 Spectrophotometer Handbook; Hach Company: Loveland, CO, USA, 1995; pp. 509-515. 
15. Hach Company. DR/4000 Procedure Nitrate Method 8192. Available online: http://www.hach.com/fmmimghach?/CODE\%3ANITRATE_PP_LOW_CDR_E2060\%7C1 (accessed on 8 January 2007).

16. United States Environmental Protection Agency (USEPA). Nutrient Criteria Technical Guidance Manual: Rivers and Streams; EPA 822-B-00-002; United States Environmental Protection Agency Office of Water: Washington, DC, USA, 2000.

17. Dodds, W.K.; Jones, J.R.; Welch, E.B. Suggested classification for stream trophic state: Distributions of temperate stream types by chlorophyll, total N and P. Water Resour. 1998, 32, $1455-1462$.

18. Maidment, D.R. Handbook of Hydrology; McGraw-Hill Inc.: New York, NY, USA, 1993; pp. 11:37-11:54.

19. Cook, M.R.; Murgulet, D.; Moss, N.E.; Gillett, B.; Jennings, S.P. Water-Quality Evaluation of the Little Choctawhatchee River in Southeast Alabama; Open File Report 1113; Geological Survey of Alabama: Tusculoosa, AL, USA, 2011.

20. Heath, W.H. Distributional Survey and Habitat Partitioning of Crayfish (Crustacea: Decapoda) Assemblages in Wadeable Streams in the Coastal Plains of Southeastern Alabama. Master's Thesis, Troy University, Troy, AL, USA, 2008.

21. Mullen, M.W. Little Choctawhatchee River Sampling; Center for Environmental Research and Service, Department of Biological and Environmental Sciences, Troy State University: Troy, AL, USA, 2003.

22. Mullen, M.W. Water Quality in the Choctawhatchee-Pea Rivers; Center for Environmental Research and Service, Department of Biological and Environmental Sciences, Troy State University: Troy, AL, USA, 1997.

23. Chakravarty, T.A. Water Quality and Trophic Classification of a Southeastern Watershed. Master's Thesis, Troy University: Troy, AL, USA, 2007.

24. Alabama Department of Environmental Management (ADEM). Little Choctawhatchee River (0.14-0201-120) data from 1999, 2004, and 2005. Available online: http://www.adem.state.al.us/ FieldOps/WQReports/2004SEALReport.pdf (accessed on 21 July 2008).

25. McPherson, A.K.; Moreland, R.S.; Atkins, J.B. Occurrence and Distribution of Nutrients, Suspended Sediments, and Pesticides in the Mobile River Basin, Alabama, Georgia, Mississippi, and Tennessee, 1999-2001; United States Geological Survey Circular WRI 03-4203; National Water-Quality Assessment Program, United States Geological Survey: Denver, CO, USA, 2003.

26. Berndt, M.P.; Hatzell, H.H.; Crandall, C.A.; Turtora, M.; Pittman, J.R.; Oaksford, E.T. Water Quality in the Georgia-Florida Coastal Plain; United States Geological Survey: Tallahassee, FL, USA, 1998.

27. Smith, R.A.; Alexander, R.B.; Wolman, M.G. Water quality trends in the nation's rivers. Science 1987, 235, 1607-1615.

28. Spruill, T.B.; Harned, D.A.; Ruhl, P.M.; Eimers, J.L.; McMahon, G.; Smith, K.E.; Galeone, D.R.; Woodside, M.D. Water Quality in the Albemarle-Pamlico Drainage Basin, North Carolina and Virginia, 1992-1995; United States Geological Survey Circular 1157; National Water-Quality Assessment Program, United States Geological Survey: Denver, CO, USA, 1998. 
29. Kleiss, B.A.; Coupe, R.H.; Gonthier, G.J.; Justus, B.J. Water Quality in the Mississippi Embayment, Mississippi, Louisiana, Arkansas, Missouri, Tennessee, and Kentucky, 1995-1998; United States Geological Survey Circular 1208; National Water-Quality Assessment Program, United States Geological Survey: Denver, CO, USA, 2000.

30. Atkins, J.B.; Zappia, H.; Robinson, J.L.; McPherson, A.K.; Moreland, R.S.; Harned, D.A.; Johnston, B.F.; Harvill, J.H. Water Quality in the Mobile River Basin, Alabama, Georgia, Mississippi, and Tennessee, 1999-2001; United States Geological Survey Circular 1231; National Water-Quality Assessment Program, United States Geological Survey: Reston, VA, USA, 2004.

31. Miller, J.M.; Stewart, P.M. Historical vs. current biological assemblages in the little Choctawhatchee watershed, Southeastern AL, USA. Southeast. Nat. 2013, 12, 267-282.

32. Miller, J.M. Water Quality, Mussel, Fish, and Crayfish Assemblages of the Little Choctawhatchee River: A Pre-Dam Assessment. Master's Thesis, Troy University, Troy, AL, USA, 2009.

33. United States Geological Survey. The Quality of Our Nation's Waters-Nutrients and Pesticides; United States Geological Survey Circular 1225; 1999. Available online: http://pubs.usgs.gov/circ/ circ1225/pdf/front.pdf (accessed on 21 July 2008).

34. Winger, J.G.; Duthie, H.C. Export coefficient modeling to assess phosphorus loading in an urban watershed. J. Am. Water Resour. As. 2000, 36, 1053-1061.

35. Osborne, L.L.; Wiley, M.J. Empirical relationships between land use/cover and stream water quality in an agricultural watershed. J. Environ. Manag. 1988, 26, 9-27.

36. Smolen, M.D. Phosphorus and Water Quality; Division of Agricultural Sciences and Natural Resources, Oklahoma State University: Stillwater, OK, USA, 2009. Available online: http://www.poultrywaste.okstate.edu/files/BAE-1521web.pdf (accessed on 16 November 2009).

37. Tomer, M.D.; Burkart, M.R. Long-term effects of nitrogen fertilizer use on groundwater nitrate in two small watersheds. J. Environ. Qual. 2003, 32, 2158-2171.

38. National Oceanic and Atmospheric Association (NOAA) Web Page. Historical Palmer Drought Indices. Available online: http://www.ncdc.noaa.gov/temp-and-precip/drought/historical-palmers.php (accessed on 7 October 2009).

39. Mullen, M.W. Characteristics of Pollutants in Storm Water Runoff from Dothan, Alabama Catchments: Implications for Phase II Storm Water Management; Center for Environmental Research and Service, Department of Biological and Environmental Sciences, Troy State University: Troy, AL, USA, 2000.

40. Keast, A.; Fox, M.G. Fish community structure, spatial distribution and feeding ecology in a beaver pond. Environ. Biol. Fish. 1990, 27, 201-214.

41. Omernik, J.M. The Influence of Land Use on Stream Nutrient Levels; EPA-600/2-76-014; United States Environmental Protection Agency: Washington, DC, USA, 1976.

42. Nagumo, T.; Hatano, R. Impact of nitrogen cycling associated with production and consumption of food on nitrogen pollution of stream water. Soil Sci. Plant Nutr. 2000, 46, 325-342.

43. Paul, M.J.; Meyer, J.L. Streams in the urban landscape. Annu. Rev. Ecol. Syst. 2001, 32, 333-365.

44. Omernik, J.M. Nonpoint Source-Stream Nutrient Level Relationships: A Nationwide Study; EPA-600-3-77-105; Special Studies Branch, Corvallis Environmental Research Laboratory, Office of Research and Development, United States Environmental Protection Agency: Corvallis, OR, USA, 1997. 
45. Smart, M.M.; Jones, J.R.; Sebaugh, J.S. Stream-watershed relations in the Missouri Ozark Plateau province. J. Environ. Qual. 1985, 14, 77-82.

46. Peierls, B.L.; Caraco, N.F.; Pace, M.L.; Cole, J.J. Human influence on river nitrogen. Nature 1991, 350, 386-387.

47. Chessman, B.C.; Hutton, P.E.; Burch, J.M. Limiting nutrients for periphyton growth in sub-alpine, forest, agricultural, and urban streams. Freshwater Biol. 1992, 28, 349-355.

48. Richards, C.; Host, G. Examining land use influences on stream habitats and macroinvertebrates: A GIS approach. Water Resour. Bull. 1994, 30, 729-738.

49. Hunsaker, C.T.; Levine, D.A. Hierarchical approaches to the study of water quality in rivers. Bioscience 1995, 45, 193-203.

50. White, J.D.; Prochnow, S.J.; Filstrup, C.T.; Byars, B.W. A combined watershed-water quality modeling analysis of the Lake Waco reservoir: II. Watershed and reservoir management options and outcomes. Lake Reserv. Manag. 2010, 26, 159-167.

51. O'Connor, J.; Major, J.; Grant, G. Down with the dams: Unchanging U.S. rivers. Available online: http://www.geotimes.org/mar08/article.html?id=feature_dams.html. (accessed on 7 October 2009).

(C) 2013 by the authors; licensee MDPI, Basel, Switzerland. This article is an open access article distributed under the terms and conditions of the Creative Commons Attribution license (http://creativecommons.org/licenses/by/3.0/). 